\title{
Development and Validation of an Inductively Coupled Plasma Mass Spectrometry (ICP-MS) Method for the Determination of 17 Trace Metals in Ingenol Mebutate (API)
}

\author{
Sanjeeva Reddy Kallam ${ }^{1}$, Dr. J.Srikanth ${ }^{2}$, Dr.K.Vanitha Prakash ${ }^{3}$ \\ ${ }^{l}$ Dr. Reddy's Laboratories Ltd., IDA, Bollaram, Hyderabad, Telangana, India. \\ ${ }^{2}$ MSN Labs Pvt. Ltd., Hyderabad, Telangana, India. \\ ${ }^{3}$ S. S. J. College of Pharmacy, Hyderabad, Telangana, India
}

\begin{abstract}
In this study elemental impurities method of quantitative analysis for the determination of trace metals in Ingenol mebutate (API) by ICP-MS was validated and applied. ICP-MS is a multi-element technique characterized by high selectivity, sensitivity and detection limits much lower than other multi-element techniques. Inductively coupled plasma mass spectrometry (ICP-MS) equipped with microwave digestion is considered an excellent tool for detailed characterization of the elementary composition of many samples. In this study elemental impurities method of quantitative analysis for the determination of toxic metals (As, $\mathrm{Cd}$, $\mathrm{Ni}, \mathrm{Hg}, \mathrm{Pb}$ ) and other trace metals $\mathrm{Ir}, \mathrm{Pd}, \mathrm{Pt}, \mathrm{Rh}, \mathrm{Ru}, \mathrm{Os}, \mathrm{Mo}, \mathrm{V}, \mathrm{Cu}, \mathrm{Sn}, \mathrm{Sb}, \mathrm{Bi}$ in Ingenol mebutate (API) using Indium as an internal standard by ICP-MS was validated. Several parameters have been taken into account and evaluated for the validation of method, namely: linearity, the minimum detection limit, the limit of quantification, accuracy and uncertainty. The results obtained for the recovery rates of all (17) metals between $75 \%$ and $124 \%$ were found. The detection limits of all elements studied showed the suitability of the procedure for routine analyses. Summarizing it can be concluded that the described analytical procedures to measure the mass fractions of 17 elements in Ingenol mebutate (API) samples with established traceability and evaluated uncertainty allow to obtain reliable and internationally comparable results
\end{abstract}

Keywords: ICP-MS, Microwave digestion, Multi element analysis, method validation.

\section{Introduction}

Ingenol mebutate is an API and actinic keratoses are premalignant lesions commonly encountered in dermatology, with risk factors that include fair skin types, age, and a history of chronic sun exposure. Cryotherapy is the most widely utilized treatment, but it is associated with the risk of scarring. Topical therapies, such as 5-fluorouracil or imiquimod, are disadvantageous for other reasons, including the longer duration of treatment and the risk of localized skin reactions with prolonged application, both of which may negatively impact patient adherence to treatment. Recently, the medical community has focused its attention on a new treatment for actinic keratoses called Ingenol mebutate. This medication is derived from the sap of the Euphorbia peplus plant, also known as petty spurge, radium weed, or milkweed. The sap is a white, sticky irritant that has long been used in traditional medicine for treatment of warts, corns, and nonmelanoma skin cancers. An Australian survey from 1986 regarding the use of home remedies for skin cancers and actinic keratoses described support among respondents regarding the effectiveness of the sap of Euphorbia peplus. In January 2012, Ingenol mebutate gel attained FDA approval for the treatment of actinic keratoses.

The purpose of this research article is validation of elemental method for determination of trace metals in Ingenol mebutate (represent the availability of seventeen elements in the API) by inductively coupled plasma mass spectroscopy (ICP-MS) method. Several parameters have been taken into account and evaluated for the validation of method, namely: linearity, the minimum detection limit, the limit of quantification, accuracy and uncertainty.The content of these elements can provide essential information for consumers, which is why the estimation of quality parameters is so important. In recent years, concentration patterns of trace elements were widely used in food authenticity studies.

Quality of measurements plays a very important role in many fields of our life, for instance in medicine, food Analysis, environmental studies or in the exchange of goods and services. Analytical chemistry aspires to obtain the most reliable analytical results, which must reflect unambiguous, true and clear values of the sample composition and to this end applies sophisticated instrumental techniques.We developed and applied analytical methods to measure the content of 17 major and trace elements in API (Ingenol mebutate) 
2.1 Materials and reagents

\section{Experimental}

The reference samples of Ingenol mebutate, provided as gift samples from Dr.Reddys laboratories Ltd. All chemicals were of analytical grade (Fisher grade) Nitric acid, Hydrochloric acid and all other reagents $(\mathrm{Cd}$, $\mathrm{Pb}$, As , $\mathrm{Hg}$, Ir, Pd, Pt, Rh, Ru , Os, Mo, Ni, V, Cu, Sn, Sb, Bi ,In were obtained from Merck chemical division, Mumbai. All solutions were prepared with double deionized water obtained by passing distilled water through a Millipore Milli-Q water purification system (Waters Corporation, Milford, MA, USA).

\subsection{Instrument and Operating Conditions}

The Inductively coupled plasma mass spectrometry (ICP-MS) model: Nexion 300x system was equipped with data acquision and processing software "Nexion used for the method development and validation from Perkin Elmer, USA. Microwave digester from PerkinElmer, USA.

Table 1- ICP-MS operating conditions:

\begin{tabular}{|ll|}
\hline Equipment & $:$ Inductively coupled plasma-Mass spectrometer \\
\hline ICP RF Power & $: 1600$ Watts \\
\hline Plasma gas flow & $: 18 \mathrm{Lt} / \mathrm{min}$ \\
\hline Scan mode & $:$ Peak hopping \\
\hline Mode & $:$ KED \\
\hline Cell gas A & $: \mathbf{3 . 5} \mathbf{~ m l} / \mathbf{m i n}$ \\
\hline Cell gas B & $: 0$ \\
\hline $\mathrm{RPa}$ & $: 0$ \\
\hline $\mathrm{RPq}$ & $: 0.25$ \\
\hline KED Mode Axial Field Voltage & $: 350$ \\
\hline No. of sweeps & $: 20$ \\
\hline No. of replicates & $: 3$ \\
\hline No. of readings & $: 1$ \\
\hline
\end{tabular}

\subsection{Standard and Sample preparations:}

Diluent: Transfer $31 \mathrm{~mL}$ of Conc $\mathrm{HNO} 3$ and $17 \mathrm{~mL}$ of Conc $\mathrm{HCl}$ into $1000 \mathrm{~mL}$ beaker containing $500 \mathrm{~mL}$ of Milli Q water and dilute to $1000 \mathrm{~mL}$ with Milli Q water.

\subsubsection{Preparation of Standard stock solutions:}

\subsubsection{Preparation of $100 \mathrm{ppm}$ Standard of Ir,Os,Mo,Pt,Pd,Rh,Ru,V,Ni,Sn,Sb,Bi and Cu:}

Transfer $1 \mathrm{ml}$ of $1000 \mathrm{ppm}$ Standard of each element in to $10 \mathrm{ml}$ volumetric flask individually and make up to the volume with diluent.

\subsubsection{Preparation of 10 ppm Cd \& Hg Standard:}

Transfer $100 \mu \mathrm{l}$ of $1000 \mathrm{ppm}$ Standard of $\mathrm{Cd}$ and $\mathrm{Hg}$ element in to $10 \mathrm{ml}$ volumetric flask individually and make up to the volume with diluent.

\subsubsection{Preparation of $1 \mathrm{ppm} \mathrm{Pb} \&$ as Standard:}

Transfer $1 \mathrm{ml}$ of $1000 \mathrm{ppm}$ Standard of $\mathrm{Pb}$ and As element in to $10 \mathrm{ml}$ volumetric flask individually and make up to the volume with diluent. This is 100ppm standard solution, from this $1 \mathrm{ml}$ solution transfer to 10 $\mathrm{ml}$ volumetric flask individually and make up to the volume with diluent. This is $10 \mathrm{ppm}$ standard solution, from this $1 \mathrm{ml}$ solution transfer to $10 \mathrm{ml}$ volumetric flask individually and make up to the volume with diluent.

\subsubsection{Preparation of $100 \mathrm{ppb}$ Indium Standard (Used as Internal Standard):}

Transfer $1 \mathrm{ml}$ of $1000 \mathrm{ppm}$ Indium Standard in to $10 \mathrm{ml}$ volumetric flask and make up with diluent (100ppm), from this solution transfer $100 \mu 1$ to $10 \mathrm{ml}$ volumetric flask and make up with diluent (1ppm), from this solution transfer $5 \mathrm{ml}$ to $50 \mathrm{ml}$ volumetric flask and make up with diluent.

\subsubsection{Preparation of 10J Mixed Standard:}

Transfer $500 \mu \mathrm{l}$ of 100ppm standard of Ir, Os, Mo, Pt, Pd, Rh, Ru, V, Sn, Sb, Bi, $2.5 \mathrm{ml}$ of 100ppm Ni, $5 \mathrm{ml}$ of $100 \mathrm{ppm} \mathrm{Cu}, 1.25 \mathrm{ml}$ of $10 \mathrm{ppm} \mathrm{Cd}, 750 \mu 1$ of $10 \mathrm{ppm} \mathrm{Hg}, 2.5 \mathrm{ml}$ of $1 \mathrm{ppm} \mathrm{Pb}, 750 \mu 1$ of $1 \mathrm{ppm}$ As in to a 50 $\mathrm{ml}$ volumetric flask and make up to volume with diluent.

\subsubsection{Preparation of Calibration Blank and Calibration Standards:} Preparation of Calibration Blank:

Transfer $0.5 \mathrm{ml}$ of $\mathrm{n}$-butanol and $2 \mathrm{ml}$ of $100 \mathrm{ppb}$ Indium Standard in to $10 \mathrm{~mL}$ volumetric flask and dilute up to the mark with diluent. 
Development and Validation of an Inductively Coupled Plasma Mass Spectrometry $($ ICP-MS)...

\subsubsection{Preparation of 0.5 J Calibration Standard:}

Transfer $0.5 \mathrm{ml}$ of $10 \mathrm{~J}$ Standard in to $10 \mathrm{ml}$ volumetric flask and add $2 \mathrm{~mL}$ of $10 \mathrm{ppm}$ Indium Standard, $0.5 \mathrm{ml} \mathrm{n-}$ butanol and make up with diluent.

\subsubsection{Preparation of 1.0 J Calibration Standard:}

Transfer 1.0ml of 10J Standard in to $10 \mathrm{ml}$ volumetric flask and add $2 \mathrm{~mL}$ of $10 \mathrm{ppm}$ Indium Standard, $0.5 \mathrm{ml} \mathrm{n}$ butanol and made up with diluent.

\subsubsection{Preparation of 2.0 J Calibration Standard:}

Transfer $2.0 \mathrm{ml}$ of 10J Standard in to $10 \mathrm{ml}$ volumetric flask and add $2 \mathrm{~mL}$ of $10 \mathrm{ppm}$ Indium Standard, 0.5 $\mathrm{ml}$ n-butanol and make up with diluent.

\subsubsection{Preparation of Test sample:}

Transfer $100 \mathrm{mg}$ of sample for each preparation in to Teflon vessel (digestion tube) Add $3 \mathrm{~mL}$ of Conc HNO3, Load the vessels in microwave sample digester and start the digestion program as below

Table 2- Optimized Conditions

\begin{tabular}{|l|l|l|l|l|}
\hline Temperature $\left.{ }^{\circ} \mathbf{C}\right]$ & $\begin{array}{l}\text { Pressure } \\
{[\mathbf{b a r}]}\end{array}$ & $\begin{array}{l}\text { Ramp } \\
(\text { minutes) }\end{array}$ & $\begin{array}{l}\text { Hold } \\
(\text { minutes })\end{array}$ & $\mathbf{P}[\%]$ \\
\hline 160 & 50 & 10 & 25 & 60 \\
\hline 50 & 50 & 0 & 25 & 0 \\
\hline 50 & 50 & 0 & 0 & 0 \\
\hline 50 & 50 & 0 & 0 & 0 \\
\hline 50 & 50 & 0 & 0 & 0 \\
\hline
\end{tabular}

After completion of digestion carefully transfer the solution to $10 \mathrm{~mL}$ volumetric flask, rinse the teflon vessels with diluent and transfer the solution to the same volumetric flask. Add $2 \mathrm{~mL}$ of $100 \mathrm{ppb}$ Indium Standard as internal standard, $0.5 \mathrm{ml} \mathrm{n}$-butanol to each and make up to the mark with diluent.

\section{Preparation and Reagent Blank:}

Prepare as test sample procedure without addition of sample.

Table 3- Calculation of $\mathbf{J}$ value:

$\mathbf{J}$ value is calculated by the using the formula

$\mathbf{J}(\mathbf{p p b})=\quad$ PDE $\quad$ X 1000 (Dilution Factor=Dilution in ml/sample weight in gms)

\begin{tabular}{|c|c|c|c|c|c|c|c|c|}
\hline Element & $\begin{array}{l}\text { PDE } \\
\text { Value }\end{array}$ & $\begin{array}{l}\text { Dilution } \\
\text { factor }\end{array}$ & $\begin{array}{l}\text { 1J value } \\
\text { (wrt std } \\
\text { in ppb) }\end{array}$ & $\begin{array}{l}\text { 1J value } \\
\text { (wrt sample } \\
\text { in ppm) }\end{array}$ & $\begin{array}{l}\text { 0.5J value } \\
\text { (wrt std in } \\
\text { ppb) }\end{array}$ & $\begin{array}{l}\text { 0.5J value } \\
\text { (wrt sample } \\
\text { in ppm) }\end{array}$ & $\begin{array}{l}\text { 2J value } \\
\text { (wrt std } \\
\text { in ppb) }\end{array}$ & $\begin{array}{l}\text { 2J value } \\
\text { (wrt sample } \\
\text { in ppm) }\end{array}$ \\
\hline Cadmium (Cd) & 2.5 & 100 & 25 & 2.5 & 12.5 & 1.25 & 50 & 5 \\
\hline Molybdenum (Mo) & 10 & 100 & 100 & 10 & 50 & 5 & 200 & 20 \\
\hline Rhodium (Rh) & 10 & 100 & 100 & 10 & 50 & 5 & 200 & 20 \\
\hline Palladium (Pd) & 10 & 100 & 100 & 10 & 50 & 5 & 200 & 20 \\
\hline Osmium (Os) & 10 & 100 & 100 & 10 & 50 & 5 & 200 & 20 \\
\hline Platinum $(\mathrm{Pt})$ & 10 & 100 & 100 & 10 & 50 & 5 & 200 & 20 \\
\hline Iridium (Ir) & 10 & 100 & 100 & 10 & 50 & 5 & 200 & 20 \\
\hline Ruthenium (Ru) & 10 & 100 & 100 & 10 & 50 & 5 & 200 & 20 \\
\hline Copper $(\mathrm{Cu})$ & 100 & 100 & 1000 & 100 & 500 & 50 & 2000 & 200 \\
\hline Vanadium (V) & 10 & 100 & 100 & 10 & 50 & 5 & 200 & 20 \\
\hline Lead $(\mathrm{Pb})$ & 0.5 & 100 & 5 & 0.5 & 2.5 & 0.25 & 10 & 1 \\
\hline Arsenic (As) & 0.15 & 100 & 1.5 & 0.15 & 0.75 & 0.075 & 3 & 0.3 \\
\hline Mercury $(\mathrm{Hg})$ & 1.5 & 100 & 15 & 1.5 & 7.5 & 0.75 & 30 & 3 \\
\hline $\operatorname{Tin}(\mathrm{Sn})$ & 10 & 100 & 100 & 10 & 50 & 5 & 200 & 20 \\
\hline Bismuth(Bi) & 10 & 100 & 100 & 10 & 50 & 5 & 200 & 20 \\
\hline Antimony(Sb) & 10 & 100 & 100 & 10 & 50 & 5 & 200 & 20 \\
\hline Nickel (Ni) & 50 & 100 & 500 & 50 & 250 & 25 & 1000 & 100 \\
\hline
\end{tabular}

Note: Working solution $10 \mathrm{ppb}$ is equivalent to $1 \mathrm{ppm}$ with respect to sample.

\subsection{METHOD VALIDATION}

The validation of the elemental analysis method was carried out as per the international guidelines

ISO/IEC 17025:2005. The parameters assessed were linearity, precision, accuracy, LOD and LOQ. 
Development and Validation of an Inductively Coupled Plasma Mass Spectrometry (ICP-MS)...

\subsubsection{Accuracy}

The accuracy of the method was evaluated in triplicate at three concentration levels $50 \%, 100 \%$ and $150 \%$ of test concentration $10 \mathrm{mg} / \mathrm{mL}$. The percentage of recoveries were calculated from the slope and YIntercept of the calibration curve. The accuracy study of metals was carried out in triplicate at $50 \%, 100 \%$, \& $150 \%$ of specification level $(0.1 \%)$ to the Ingenol mebutate analyte concentration $(1000 \mu \mathrm{g} / \mathrm{mL})$. The percentages of recoveries for metals were calculated from the slope and $\mathrm{Y}$ - Intercept of the calibration curve

\subsubsection{Precision}

The precision of the elemental method was evaluated by carrying out six independent preparations of Ingenol mebutate (each metal) test samples against internal standard and calculate the \%RSD of metals.

\subsubsection{Linearity}

The purpose of the test for linearity is to demonstrate that the entire analytical system exhibits a linear response and is directly proportional over the relevant concentration range for the target concentration of the analyte. The linear regression data for the calibration plot is indicative of a good linear relationship between metal area and concentration over a wide range. The correlation coefficient was indicative of high significance.

\subsubsection{Limit of Detection \& Limit of Quantitation}

The LOD can be defined as the smallest level of metal ion that gives a measurable response and LOQ was determined as the lowest amount of analyte that was reproducibly quantified. These two parameters were calculated using the formula based on the standard deviation of the response and the slope. LOD and LOQ were calculated by using equations, $\mathrm{LOD}=3.3 \times \mathrm{SD} / \mathrm{S}$ and $\mathrm{LOQ}=10 \times \mathrm{SD} / \mathrm{s}$, where $\mathrm{SD}=$ standard deviation, $\mathrm{S}=$ slope of the calibration curve.

\subsubsection{Solution stability:}

The solution stability of Ingenol Mebutate in the heavy metals method of 10J Solution shall be used on the same day of preparation. (Valid up to $24 \mathrm{hrs}$ )

Table 4- Limit of Detection and Limit of Quantification LOD \& LOQ Values

\begin{tabular}{|c|c|c|c|c|c|c|c|c|c|c|c|c|}
\hline \multirow{2}{*}{$\begin{array}{l}\text { Standard } \\
\text { Concentra } \\
\text { tion } \\
\text { in ppb }\end{array}$} & \multicolumn{12}{|c|}{ Intensity } \\
\hline & \multicolumn{3}{|c|}{$\mathbf{R h}$} & $\mathbf{B i}$ & $\mathbf{V}$ & Ru & Pd & $\mathbf{P t}$ & $\mathbf{S b}$ & Sn & Mo & Os \\
\hline 10 & \multicolumn{2}{|c|}{234044.3} & $\begin{array}{l}198158 . \\
2\end{array}$ & $\begin{array}{l}254879 . \\
6\end{array}$ & $\begin{array}{l}40914 . \\
8\end{array}$ & $\begin{array}{l}37027 . \\
6\end{array}$ & $\begin{array}{l}\begin{array}{l}50979 . \\
1\end{array} \\
\end{array}$ & $\begin{array}{l}75436 . \\
3\end{array}$ & $\begin{array}{l}43499 . \\
8\end{array}$ & $\begin{array}{l}35252 . \\
4\end{array}$ & $\begin{array}{l}20025 . \\
6\end{array}$ & 56587.2 \\
\hline 20 & \multicolumn{2}{|c|}{469357.1} & $\begin{array}{l}394103 . \\
7 \\
\end{array}$ & $\begin{array}{l}507877 . \\
2\end{array}$ & $\begin{array}{l}78742 . \\
4\end{array}$ & $\begin{array}{l}74564 . \\
1\end{array}$ & $\begin{array}{l}102997 \\
.0\end{array}$ & $\begin{array}{l}147383 \\
.4\end{array}$ & $\begin{array}{l}85529 . \\
6\end{array}$ & $\begin{array}{l}70286 . \\
8\end{array}$ & $\begin{array}{l}40340 . \\
4\end{array}$ & $\begin{array}{l}112479 . \\
5\end{array}$ \\
\hline 25 & \multicolumn{2}{|c|}{569049.6} & $\begin{array}{l}481786 . \\
5\end{array}$ & $\begin{array}{l}612050 . \\
6\end{array}$ & $\begin{array}{l}93861 . \\
3\end{array}$ & $\begin{array}{l}90004 . \\
0\end{array}$ & $\begin{array}{l}124394 \\
.7\end{array}$ & $\begin{array}{l}179652 \\
.2 \\
\end{array}$ & $\begin{array}{l}103438 \\
.8 \\
\end{array}$ & $\begin{array}{l}85281 . \\
5 \\
\end{array}$ & $\begin{array}{l}49027 . \\
9\end{array}$ & $\begin{array}{l}136065 . \\
3\end{array}$ \\
\hline 30 & \multicolumn{2}{|c|}{661969.4} & $\begin{array}{l}561419 . \\
3\end{array}$ & $\begin{array}{l}718631 . \\
4\end{array}$ & $\begin{array}{l}109984 \\
.8\end{array}$ & $\begin{array}{l}106153 \\
.0\end{array}$ & $\begin{array}{l}146102 \\
.0\end{array}$ & $\begin{array}{l}210510 \\
.8\end{array}$ & $\begin{array}{l}122873 \\
.8\end{array}$ & $\begin{array}{l}100048 \\
.8\end{array}$ & $\begin{array}{l}57684 . \\
7\end{array}$ & $\begin{array}{l}159386 . \\
5\end{array}$ \\
\hline 40 & 886418. & & $\begin{array}{l}747979 . \\
8\end{array}$ & $\begin{array}{l}949981 . \\
8\end{array}$ & $\begin{array}{l}145118 \\
.0\end{array}$ & $\begin{array}{l}140284 \\
.4\end{array}$ & $\begin{array}{l}195102 \\
.7\end{array}$ & $\begin{array}{l}280349 \\
.8\end{array}$ & $\begin{array}{l}162924 \\
.1\end{array}$ & $\begin{array}{l}132582 \\
.8\end{array}$ & $\begin{array}{l}77083 . \\
9\end{array}$ & $\begin{array}{l}211649 . \\
6\end{array}$ \\
\hline 50 & 1084558 & & $\begin{array}{l}917704 . \\
9\end{array}$ & $\begin{array}{l}116662 \\
3.4 \\
\end{array}$ & $\begin{array}{l}177180 \\
.0\end{array}$ & $\begin{array}{l}173266 \\
.8 \\
\end{array}$ & $\begin{array}{l}240046 \\
.1 \\
\end{array}$ & $\begin{array}{l}343275 \\
.0\end{array}$ & $\begin{array}{l}200457 \\
.3 \\
\end{array}$ & $\begin{array}{l}162956 \\
.1\end{array}$ & $\begin{array}{l}94142 . \\
9 \\
\end{array}$ & $\begin{array}{l}259725 . \\
7\end{array}$ \\
\hline Std Error & 10672.8 & & $\begin{array}{l}7745.86 \\
9\end{array}$ & $\begin{array}{l}10419.2 \\
25\end{array}$ & $\begin{array}{l}1572.5 \\
41\end{array}$ & $\begin{array}{l}1401.0 \\
43\end{array}$ & $\begin{array}{l}2036.3 \\
81\end{array}$ & $\begin{array}{l}2450.5 \\
78\end{array}$ & $\begin{array}{l}1179.9 \\
74\end{array}$ & $\begin{array}{l}1338.0 \\
71\end{array}$ & $\begin{array}{l}847.21 \\
6\end{array}$ & $\begin{array}{l}2209.70 \\
9\end{array}$ \\
\hline Slope & 21149.5 & & $\begin{array}{l}17898.8 \\
31\end{array}$ & $\begin{array}{l}22632.5 \\
26\end{array}$ & $\begin{array}{l}\text { 3387.3 } \\
51\end{array}$ & $\begin{array}{l}3379.3 \\
15\end{array}$ & $\begin{array}{l}4698.8 \\
80\end{array}$ & $\begin{array}{l}6679.5 \\
25\end{array}$ & $\begin{array}{l}3913.3 \\
10\end{array}$ & $\begin{array}{l}3173.1 \\
92\end{array}$ & $\begin{array}{l}1848.0 \\
63\end{array}$ & $\begin{array}{l}5048.87 \\
1\end{array}$ \\
\hline LOD & 1.514 & & 1.298 & 1.381 & 1.393 & 1.244 & 1.300 & 1.101 & 0.905 & 1.265 & 1.375 & 1.313 \\
\hline LOQ & 5.046 & & 4.328 & 4.604 & 4.642 & 4.146 & 4.334 & 3.669 & 3.015 & 4.217 & 4.584 & 4.377 \\
\hline $\begin{array}{l}\text { Standar } \\
\mathrm{d}\end{array}$ & Intensity & $\begin{array}{l}\text { Standar } \\
\text { d }\end{array}$ & Inte & ssity & & & $\begin{array}{l}\text { Standar } \\
\text { d }\end{array}$ & $\begin{array}{l}\text { Intensit } \\
\text { y }\end{array}$ & $\begin{array}{l}\text { Standar } \\
\mathrm{d}\end{array}$ & $\begin{array}{l}\text { Intensit } \\
\mathrm{y}\end{array}$ & $\begin{array}{l}\text { Standar } \\
\mathrm{d}\end{array}$ & Intensity \\
\hline & $\mathrm{Ni}$ & in $\mathrm{ppb}$ & $\mathrm{Cu}$ & & po & & & $\mathrm{Cd}$ & in $\mathrm{ppb}$ & $\mathrm{Hg}$ & & $\mathrm{Pb}$ \\
\hline 50 & 312832.1 & 100 & 782 . & 24.6 & 50 & 8.0 & 2.50 & 6660.8 & 1.50 & 4182.6 & 0.50 & 7637.4 \\
\hline 100 & 631212.1 & 200 & & & 00 & 7.7 & 5.00 & 13329.5 & 3.00 & 8257.7 & 1.00 & 14980.9 \\
\hline 125 & 769934.6 & 250 & $\begin{array}{l}191 \\
7 \\
\end{array}$ & 644. & 75 & 5.0 & 6.25 & 16063.5 & 3.75 & 10107.6 & 1.25 & 18150.5 \\
\hline
\end{tabular}


Development and Validation of an Inductively Coupled Plasma Mass Spectrometry (ICP-MS)...

\begin{tabular}{|l|l|l|l|l|l|l|l|l|l|l|l|}
\hline $\mathbf{1 5 0}$ & 908459.4 & 300 & $\begin{array}{l}2951868 . \\
6\end{array}$ & 0.450 & 929.4 & 7.50 & 19121.2 & 4.50 & 11971.3 & 1.50 & 21048.8 \\
\hline $\mathbf{2 0 0}$ & $\begin{array}{l}1211043 . \\
3\end{array}$ & 400 & $\begin{array}{l}3921524 . \\
1\end{array}$ & 0.600 & 1250.7 & 10.00 & 25508.5 & 6.00 & 15723.6 & 2.00 & 27892.9 \\
\hline $\mathbf{2 5 0}$ & 1490363. & 500 & $\begin{array}{l}4844122 . \\
1\end{array}$ & 0.750 & 1551.4 & 12.50 & 31638.6 & 7.50 & 19492.6 & 2.50 & 34184.9 \\
\hline $\begin{array}{l}\text { Std } \\
\text { Error }\end{array}$ & $\begin{array}{l}10588.68 \\
9\end{array}$ & $\begin{array}{l}\text { Std } \\
\text { Error }\end{array}$ & $\begin{array}{l}212542.5 \\
50\end{array}$ & $\begin{array}{l}\text { Std } \\
\text { Error }\end{array}$ & 26.493 & $\begin{array}{l}\text { Std } \\
\text { Error }\end{array}$ & 185.526 & $\begin{array}{l}\text { Std } \\
\text { Error }\end{array}$ & 107.731 & $\begin{array}{l}\text { Std } \\
\text { Error }\end{array}$ & 322.370 \\
\hline Slope & 5864.973 & Slope & $\begin{array}{l}10623.20 \\
5\end{array}$ & Slope & $\begin{array}{l}1979.34 \\
5\end{array}$ & Slope & $\begin{array}{l}2486.71 \\
2\end{array}$ & Slope & $\begin{array}{l}2536.71 \\
6\end{array}$ & Slope & 13176.74 \\
& & & & & & & & \\
\hline LOD & 5.958 & LOD & 66.024 & LOD & 0.044 & LOD & 0.246 & LOD & 0.140 & LOD & 0.081 \\
\hline LOQ & $\mathbf{1 8 . 0 5 4}$ & LOQ & $\mathbf{2 0 0 . 0 7 4}$ & LOQ & $\mathbf{0 . 1 3 4}$ & LOQ & $\mathbf{0 . 7 4 6}$ & LOQ & $\mathbf{0 . 4 2 5}$ & LOQ & $\mathbf{0 . 2 4 5}$ \\
\hline
\end{tabular}

Linearity: Using calibration solutions calibration curves: $y=a x+b$, were determined, where $y$ is the signal intensity and $x$ is the know concentration of the given analyte in the calibration solution. The linearity of the calibration curve was considered acceptable when the correlation factor $R>0.995$ (Table 5).

Table 5- Linearity Data

\begin{tabular}{|l|l|l|l|}
\hline Element & Correlation coefficient & Element & Correlation coefficient \\
\hline $\mathrm{Rh}$ & 0.99509 & $\mathrm{Cd}$ & 0.99996 \\
\hline $\mathrm{Ir}$ & 0.99547 & $\mathrm{Pt}$ & 0.99997 \\
\hline $\mathrm{Bi}$ & 0.99586 & $\mathrm{Hg}$ & 0.99997 \\
\hline $\mathrm{Ni}$ & 0.99777 & $\mathrm{Sb}$ & 0.99997 \\
\hline $\mathrm{Cu}$ & 0.99978 & $\mathrm{Sn}$ & 0.99998 \\
\hline $\mathrm{V}$ & 0.99996 & $\mathrm{~Pb}$ & 0.99997 \\
\hline $\mathrm{As}$ & 0.99985 & $\mathrm{Mo}$ & 0.99997 \\
\hline $\mathrm{Ru}$ & 0.99995 & $\mathrm{Os}$ & 0.99992 \\
\hline $\mathrm{Pd}$ & 0.99997 & & \\
\hline
\end{tabular}

Table 6- Accuracy Data

\begin{tabular}{|c|c|c|c|c|c|c|}
\hline Element & $\begin{array}{l}\text { Test }+50 \% \\
\text { spike }\end{array}$ & $\%$ Recovery & $\begin{array}{l}\text { Test }+100 \% \\
\text { spike }\end{array}$ & $\%$ Recovery & $\begin{array}{l}\text { Test +150\% } \\
\text { spike }\end{array}$ & $\%$ Recovery \\
\hline Sample Weight & $101.77 \mathrm{mg}$ & NA & & & & \\
\hline $\mathrm{Rh}$ & 2.657 & 104 & 5.761 & 100 & 12.013 & 102 \\
\hline $\mathrm{Ir}$ & 2.715 & 105 & 5.961 & 99 & 12.061 & 104 \\
\hline $\mathrm{Bi}$ & 2.625 & 102 & 6.546 & 85 & 11.818 & 102 \\
\hline $\mathrm{Ni}$ & 13.279 & 103 & 37.287 & 124 & 55.584 & 103 \\
\hline $\mathrm{Cu}$ & 33.257 & 105 & 71.264 & 107 & 108.643 & 106 \\
\hline $\mathrm{V}$ & 4.887 & 99 & 9.941 & 102 & 14.963 & 101 \\
\hline As & 0.059 & 100 & 0.115 & 110 & 0.178 & 103 \\
\hline $\mathrm{Ru}$ & 4.838 & 99 & 9.714 & 100 & 14.644 & 100 \\
\hline $\mathrm{Pd}$ & 4.636 & 101 & 9.153 & 102 & 13.751 & 102 \\
\hline $\mathrm{Cd}$ & 0.998 & 101 & 1.982 & 107 & 2.986 & 105 \\
\hline $\mathrm{Pt}$ & 4.449 & 101 & 9.056 & 100 & 13.296 & 103 \\
\hline $\mathrm{Hg}$ & 0.551 & 100 & 1.108 & 106 & 1.664 & 106 \\
\hline $\mathrm{Sb}$ & 4.033 & 101 & 8.064 & 109 & 12.270 & 105 \\
\hline $\mathrm{Sn}$ & 5.31 & 101 & 10.168 & 103 & 14.929 & 103 \\
\hline $\mathrm{Pb}$ & 0.262 & 89 & 0.539 & 95 & 0.755 & 92 \\
\hline Mo & 5.132 & 101 & 10.309 & 103 & 15.417 & 102 \\
\hline Os & 4.789 & 100 & 9.714 & 98 & 14.409 & 102 \\
\hline
\end{tabular}

\section{Results and Discussion}

To establish and validate an efficient method for elemental analysis of Ingenol mebutate in Active pharmaceutical ingredients, preliminary tests were performed. Different spectrometric conditions were employed for the analysis of the Ingenol mebutate active pharmaceutical ingredients. Finally the analysis was performed by using diluent: Conc HNO3 and Conc $\mathrm{HCl}$ in the ratio of $31 \mathrm{~mL}$ and $17 \mathrm{Ml}$ into $1000 \mathrm{~mL}$ of Milli $\mathrm{Q}$ water The proposed method was optimized to give very reliable results .The optimized spectrometric operating conditions were given in table 1.

Precision was evaluated by a known concentration of metal ions of Ingenol mebutate was injected six times and corresponding areas were recorded and \% RSD was calculated and found within the limits. The low \% RSD value was indicated that the method was precise and reproducible. Accuracy of the method was proved by performing recovery studies of Ingenol mebutate for each metal ions thrice at 50\%, 100\% and $150 \%$, level. Recoveries of each metal namely $(\mathrm{Cd}, \mathrm{Pb}, \mathrm{As}, \mathrm{Hg}, \mathrm{Ir}, \mathrm{Pd}, \mathrm{Pt}, \mathrm{Rh}, \mathrm{Ru}, \mathrm{Os}, \mathrm{Mo}, \mathrm{Ni}, \mathrm{V}, \mathrm{Cu}, \mathrm{Sn}, \mathrm{Sb}, \mathrm{Bi}$ ranges from $75 \%$ to $126 \%$ in proposed method and the results were shown in the (Table 6). 
Linearity was established by analyzing different concentrations for metals of ,Ir, Pd, Pt, Rh, Ru, Os, Mo, V, Sn, $\mathrm{Sb}, \mathrm{Bi} 10 \%, 20 \%, 25 \%, 30 \%, 40 \%$ and $50 \%$ level and $\mathrm{Ni}, \mathrm{Cu}, \mathrm{As}, \mathrm{Cd}, \mathrm{Hg} \& \mathrm{~Pb} 50 \%, 100 \%, 125 \%$ $150 \%, 200 \%, 250 \%$ of Ingenol mebutate metal ions. The calibration curve was plotted with the area obtained versus concentration of Ingenol mebutate metal ions, In the present study concentrations were chosen ranging between 10ppb to $250 \mathrm{ppb}$ of Ingenol mebutate metal ions. The linear regression data for the calibration plot is indicative of a good linear relationship between peak area and concentration over a wide range. The correlation coefficient was indicative of high significance and the results were shown in the (Table 5)

\section{Conclusion}

A new ICP-MS method has been developed for seventeen trace metals of Ingenol mebutate namely $\mathrm{Cd}, \mathrm{Pb}, \mathrm{As}, \mathrm{Hg}, \mathrm{Ir}, \mathrm{Pd}, \mathrm{Pt}, \mathrm{Rh}, \mathrm{Ru}, \mathrm{Os}, \mathrm{Mo}, \mathrm{Ni}, \mathrm{V}, \mathrm{Cu}, \mathrm{Sn}, \mathrm{Sb}, \mathrm{Bi}$ in Active pharmaceutical in gradients. The developed method was validated and it was found to be selective, precise, accurate and linear it can be used for the routine analysis of Ingenol mebutate in Active pharmaceutical ingredients. Several parameters have been taken into account and evaluated for the validation of method: the limit of detection ranged between $(0.0044$ 66.024) for the 17 metals studied ensures the minimum limit of quantification required for 17 Determination of metals in Ingenol mebutate by ICP-MS (0.245-0200.074); good linearity (correlation factor $R>0.995)$.

The validation studies were carried out in accordance with international guidelines ISO/IEC 17025:2005. Finally it was concluded that the method is simple, selective, and cost effective and has the ability to detect all seventeen metals of Ingenol mebutate found in Active pharmaceutical in gradients.

Quantitative analysis by ICP-MS has been proven to be a powerful tool for rapid determination of elements and the method is particularly useful for the analysis of elemental impurity samples.

\section{Acknowledgements}

We would like to thank Dr. J. Srikanth from MSN Labs Pvt Ltd, Hyderabad, India and Dr.K.Vanitha Prakash from SSJ College of Pharmacy, Hyderabad, India, for giving good support.

\section{References}

[1]. ICH Q2 (R1), Validation of Analytial procedures, Text and Methodology, International Conference on Harmonization. Geneva. 2005. p. 1-17.

[2]. Maria Chudzinska $•$ Anna Debska $\cdot$ Danuta Baralkiewicz, Method validation for determination of 13 Elements in honey samples by ICP-MS, Springerlink.com, Accred Qual Assur (2012) 17:65-73

[3]. C. Voica1, a. Dehelean1, A. Iordache, I. Geana, Method validation for determination of metals in soils by ICP-MS, Romanian Reports in Physics, Vol. 64, No. 1, P. 221-231, 2012

[4]. Cezara Voica, Adriana Dehelean and A Pamula, Method validation for determination of heavy metals In wine and slightly alcoholic beverages by ICP-MS, Journal of Physics: Conference Series 182 (2009) 012036

[5]. ISO (1993) Guide to the expression of uncertainty in measurement (GUM). International Organization for Standardization, Geneva; also JCGM 100:2008

[6]. EURACHEM/CITAC (2000) Quantifying uncertainty in analytical measurement, 2nd edn. LGC, Teddington

[7]. Koellensperger G, Hann S, Nurmi J, Prohaska T, Stingeder G (2003) J Anal At Spectrom 18:1047-1055

[8]. Kment P, Mihaljevic M, Ettler V, Šebek O, Strnad L, Rohlova L 2005 Food Chem. 91 157-65.

[9]. Ammann A A 2007 J. Mass Spectrom. 42 419-27

[10]. ISO 9004-4:1993, Total Quality Management. Part 2. Guidelines for quality improvement. ISO, Geneva (1993).

[11]. ISO/TS 28037:2010, Determination and use of straight-line calibration functions. ISO, Geneva (2010).

[12]. ISO/IEC 17025:2005 A General requirements for the competence of testing and calibration laboratories

[13]. Elemental impurities USP 39, General Chapters USP <232〉 (Limits) and <233>

[14]. Erika Matoso; Solange Cadore, Development of a digestion method for the determination of inorganic contaminants in polyvinyl acetate (PVAc), Journal of the Brazilian Chemical Society vol.19 no.7 São Paulo 2008

[15]. kazuhiro_sato kaoru_fujimoto, Development of new nickel based catalyst for tar reforming with superior resistance to sulfur poisoning and coking in biomass gasification, Catalysis_Communications Volume 8, Issue 11, 2007, Pages 1697-1701 